\title{
Physicochemical and Mineralogical Characterizations of Wastes Coming from Phosphate Ore Processing of Hahotoé and Kpogamé Mines
}

\author{
Moursalou Koriko ${ }^{*}{ }^{\circledR}$, Dodji Zounon1, Sanonka Tchegueni1, Diyadola Dihéénane Bafai1, \\ Koffi Agbegnigan Degbe1, Koffi Fiaty², Patrick Drogui ${ }^{3}$, Gado Tchangbedji ${ }^{1}$ \\ ${ }^{1}$ Laboratoire GTVD (Gestion Traitement et Valorisation des Déchets), Université de Lomé, Lomé, Togo \\ ${ }^{2}$ Laboratoire d'Automatique, de Génie des Procédés et de Génie Pharmaceutique (LAGEPP), Bâtiment CPE, Université Claude \\ Bernard Lyon, Villeurbanne Cedex, France \\ ${ }^{3}$ Centre Eau Terre Environnement de l'Institut National de la Recherche Scientifique (INRS)-ETE, Quebec City, Canada \\ Email: ^moursalou7@hotmail.com
}

How to cite this paper: Koriko, M., Zounon, D., Tchegueni, S., Bafai, D.D., Degbe, K.A., Fiaty, K., Drogui, P. and Tchangbedji, G. (2021) Physicochemical and Mineralogical Characterizations of Wastes Coming from Phosphate Ore Processing of Hahotoé and Kpogamé Mines. Journal of Minerals and Materials Characterization and Engineering, 9, 390-405.

https://doi.org/10.4236/jmmce.2021.94027

Received: June 21, 2021

Accepted: July 26, 2021

Published: July 29, 2021

Copyright $\odot 2021$ by author(s) and Scientific Research Publishing Inc. This work is licensed under the Creative Commons Attribution International License (CC BY 4.0).

http://creativecommons.org/licenses/by/4.0/

\begin{abstract}
In the framework of various phosphates discharges valorization, we have realized physicochemical and mineralogical characterizations of these discharges. We have undertaken the physicochemical and mineralogical characterizations of this waste by Fourier Transform Infrared Spectroscopy (FTIR), X-Ray Diffraction (XRD), thermal analysis and Atomic Emission Spectrometry Coupled to an Inductive Plasma Source. The results of these analyze show that phosphate sludge and screen rejects could be used in ceramics, in the manufacture of aggregates, in agriculture and other fields. On the other hand, rich magnetic waste could be used in heterogeneous photocatalysis in waste liquids treatment.
\end{abstract}

Keywords

Characterization, Valorization, Waste, Treatment, Phosphate Rock

\section{Introduction}

The valorization of mining industry waste has interested researchers and scientists in exporting countries for some years. Unloaded at the plant, the ores are then treated. They are homogenized by dosing different qualities depending on the quarries, then sent to screening machines and gravimetric separation cyc- 
lones. Mixed with sea water, the phosphates are then dewatered once and rinsed with fresh water. They are brought to low moisture content by drying in large horizontal kilns. After recovery of the fines, final screening and removal of iron oxides in an electromagnetic separator, the phosphate is ready for shipment. Effluents and dust from the management of tailings and waste rock from the manufacturing process must be treated as they have a significant impact on the environment and can be toxic to varying degrees to humans, animals and plants. The effluents may be acidic or alkaline and contain dissolved metals and/or complex soluble and insoluble organic components entrained during ore processing, as well as organic substances that may be naturally occurring, such as carboxylic acids. There are many options for managing tailings and waste rock. The most common methods are discharge of sludge into ponds, backfilling of underground or open pit mines or construction of tailings dams with the tailings or waste rock, unloading of the more or less dry tailings or waste rock onto waste heaps, use of the tailings or waste rock as a material for land reclamation (e.g. aggregates), construction (bricks) or reclamation, dry storage of thickened tailings and discharge of tailings into surface water (sea, lake, river, etc.) or groundwater. The long-term consequences of this tailings and waste rock management process are accumulations of metals in plants and animals, soil contamination, loss of human and/or animal life.

The composition of the phosphate rock depends especially on the type and origin. Sedimentary phosphate rock contains a high concentration of heavy metals such as $\mathrm{U}, \mathrm{Th}, \mathrm{Cd}, \mathrm{As}, \mathrm{Sb}, \mathrm{V}, \mathrm{Cr}, \mathrm{Zn}, \mathrm{Cu}, \mathrm{Ni}$, etc. [1]. As there are currently no commercial means of removing these pollutants, their concentration in the sludge is critical in terms of reuse possibilities. These concentrations vary according to the sources of phosphate rock but also within the same deposit. For this reason, it was approved to take new samples of sludge and water to characterize them.

The treatment of the raw ore (settling, screening, cycloning) followed by the spin-rinsing with fresh water, drying and demagnetization to obtain rich Togo natural phosphate ore, generates four (4) types of wastes that are: waste from rejects to screens, phosphate sludge from washing, dust and finally magnetic products or magnetic rejects [2] [3] [4] [5] [6].

The management and recovery of this waste is a major concern for research. Indeed, the current methods of these wastes management are inadequate with the achievement of the objectives of sustainable development and induce negative impacts on the environment and human health. In the framework of reduction of these impacts, we have undertaken this study to carry out a physicochemical characterization of the tour different wastes with the main view to their recovery [7] [8] [9] [10].

\section{Materials and Methods}

\subsection{Sampling of Wastes from Hahotoe and Kpogame Mines}

A sampling campaign was carried out on the site of the phosphate raw ore 
treatment in Kpeme. After collecting different samples, sludge was decanted, dried, crushed and then sieved to obtain powders with $150 \mu \mathrm{m}$ particle size.

\subsection{Conditioning and Preparation of Samples for Analytical Purposes}

The four samples selected for analysis and characterization are shown in Figure 1. In Figure 1(a) are depicted the dusts discharged by chimneys and blown away by storage conveyors and loading, it's consisted of fine particles of enriched natural phosphates.

The material coming from the quarry is shown on Figure 1(b). It is composed of two parts namely the material phosphate which is the part having a market value and the non-essential material or gangue consisting largely of clays. This waste also called "high cut" at 2 or $3 \mathrm{~mm}$ of the screens is on average $2 \%$ by dry weight of the whole. They constitute the fractions grained from treatment waste rock. On Figure 1(c), are shown the washing sludge. They are made up of fine particles that are formed during the enrichment process of the phosphate ore by the separation of gangue through several steps which are: washing, flotation, settling, and sol-id-liquid separation. The sludge contains mainly clay mixed with seawater from the low cutoff at 45 microns at the level of the primary cyclones. Figure 1(d) depicted the magnetic waste rock. The enriched phosphate ore, wrung out and dried in ovens brought to $800^{\circ} \mathrm{C}$, passes through a magnetic band to remove metals oxides also called sterile magnetic. The magnetic purification plant generates on average $0.50 \%$ of the output tonnage in magnetic waste rock. These waste rocks have a grain size greater than 200 microns [2].

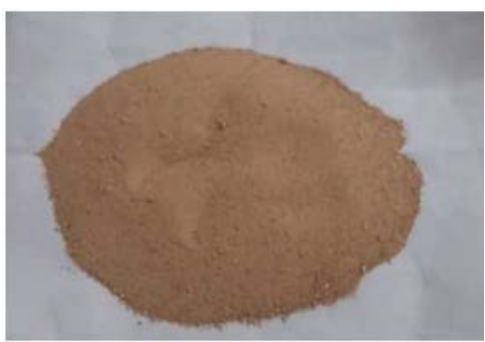

(a)

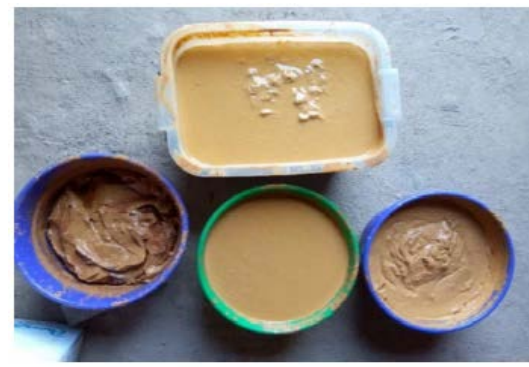

(c)

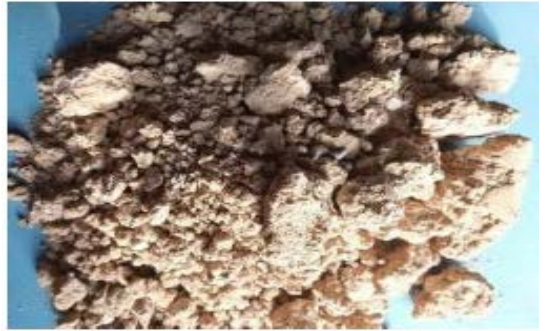

(b)

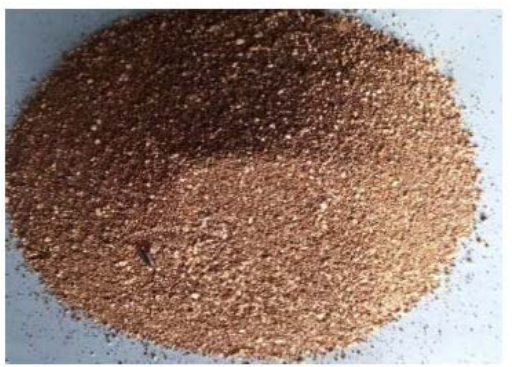

(d)

Figure 1. The different waste discharges from phosphate treatment. (a) Dust or fine particles of phosphate; (b) Waste from rejection to screens; (c) Phosphate washing sludge; (d) Magnetic waste or called sterile magnetic. 


\subsection{Analytical Techniques}

\subsubsection{Chemical's Analysis}

Chemical analysis by Inductive coupled plasma atomic emission spectroscopy (ICP-AES) was carried out at Water Earth Environment Center of the National Institute for Scientific Research (INRS) of the University of Quebec Trois Rivières (UQTR). The spectrometer used during this study is ICP-AES Dual View 5110 .

\subsubsection{Thermogravimetric and Differential Thermal Analysis} Thermogravimetric (TGA) and Differential Thermal (DTA) analyzes of samples was carried out at the Laboratory of Automatic Control and Chemical Engineering of University Claude Bernard Lyon 1 (France). The device used is "NETZSCH TG 209F122-10-210-K" type.

\subsubsection{X-Ray Diffraction (XRD) Analysis}

The mineralogical composition of the different samples was determined by X-ray diffraction at the Laboratory of Automatic Control and Chemical Engineering using a Seifert XRD 3000 TT diffractometer equipped with a diffracted beam monochromator. Experimental details of data collection are reported in Table 1.

\subsubsection{Fourier Transform Infrared Spectroscopy (FTIR) Analysis}

Fourier transform infrared (FTIR) spectroscopy was performed on $\mathrm{KBr}$ pellets containing homogeneous mixture of $2 \mathrm{mg}$ of compound and $300 \mathrm{mg} \mathrm{KBr}$ in the Laboratory of Automatic Control, Chemical Engineering and and Pharmaceutical Engineering of the University of Lyon 1 (France). The device used is the VERTEX70 type. IR scan was performed from 400 to $4000 \mathrm{~cm}^{-1}$.

\section{Results and Discussion}

\subsection{Chemical Composition of Samples}

Materials chemical compositions in minor elements are listed in Table 2 and the major elements expressed in \% in Table 3.

Table 1. Experimental details of X-ray powder-profile data collection.

\begin{tabular}{cc}
\hline Radiation & $\mathrm{Cu}, \mathrm{K} \alpha_{1,2}, \mathrm{I}\left(\lambda_{1}\right) / \mathrm{I}\left(\lambda_{2}\right)=0.5$ \\
Divergence slits & $3.00 \mathrm{~mm}$-Soller- $2.00 \mathrm{~mm}$ \\
Receiving slits & - Soller- $0.10 \mathrm{~mm}$ \\
$2 \theta$ Range $\left(^{\circ}\right)$ & $8-160$ \\
& $\theta-\theta$ \\
Step scan & $0.02^{\circ}$ \\
Step width $(2 \theta)$ & Powder (particle size $<90 \mu \mathrm{m})$ compressed in cylindrical sample holder of $24 \mathrm{~mm}$ \\
Counting time $(\mathrm{s})\left[\right.$ range $\left.\left({ }^{\circ} 2 \theta\right)\right]$ & diameter and 0.5 depth \\
Sample & Room temperature $(293 \mathrm{~K})$ \\
Temperature &
\end{tabular}


Table 2. Content of minor elements.

\begin{tabular}{|c|c|c|c|c|c|c|c|c|c|c|c|}
\hline \multirow{2}{*}{ Samples } & As & $\mathrm{Ba}$ & $\mathrm{Cd}$ & $\mathrm{Cu}$ & $\mathrm{Cr}$ & Mo & $\mathbf{N i}$ & $\mathrm{Pb}$ & $\mathrm{Sr}$ & $\mathrm{V}$ & $\mathrm{Zn}$ \\
\hline & \multicolumn{11}{|c|}{$(\mathrm{mg} / \mathrm{kg})$} \\
\hline Waste from refusal to screens & 15.1 & 140 & 33.2 & 56.3 & 300 & 9.85 & 111 & $<8$ & 497 & 174 & 354 \\
\hline Phosphate washing sludge & 39 & 156 & 27.3 & 93.5 & 699 & 15.6 & 215 & $<8$ & 535 & 330 & 729 \\
\hline Magnetic waste & 565 & 1670 & 48.5 & 385 & 330 & 247 & 1025 & 55.6 & 264 & 599 & 2375 \\
\hline Discharge of dust & $<12$ & 5.3 & 35.4 & 126 & 155 & 7.07 & 19.6 & $<8$ & 513 & 63 & 196 \\
\hline
\end{tabular}

Table 3. Content of major elements.

\begin{tabular}{|c|c|c|c|c|c|c|c|c|c|c|}
\hline \multirow{2}{*}{ Samples } & $\mathrm{Al}_{2} \mathrm{O}_{3}$ & $\mathrm{CaO}$ & $\mathrm{Fe}_{2} \mathrm{O}_{3}$ & $\mathrm{~K}_{2} \mathrm{O}$ & $\mathrm{MgO}$ & $\mathrm{MnO}$ & $\mathrm{Na}_{2} \mathrm{O}$ & $\mathrm{P}_{2} \mathrm{O}_{5}$ & $\mathrm{SiO}_{2}$ & LOI \\
\hline & \multicolumn{10}{|c|}{ (\%) } \\
\hline Waste from refusal to screens & 8.73 & 30.93 & 5.02 & 0.21 & 0.69 & 0.03 & 0.35 & 20 & 19.77 & 11.6 \\
\hline Phosphate washing sludge & 10.47 & 20.79 & 6.8 & 0.44 & 1.17 & 0.03 & 3.49 & 14.2 & 20.69 & 18.6 \\
\hline Magnetic waste & 2.83 & 22.22 & 40.42 & 0.04 & 0.17 & 1.10 & 0.30 & 15.7 & 5.17 & 9.6 \\
\hline Discharge of dust & 1.22 & 50.1 & 1.40 & 0.016 & 0.068 & 0.024 & 0.19 & 35.5 & 3.24 & 3.9 \\
\hline
\end{tabular}

The data of different minor elements (Table 2) were measured by Inductive coupled plasma atomic emission spectroscopy (ICP-AES). They show that the phosphate waste contains heavy metals as arsenic (As), cadmium (Cd), copper $(\mathrm{Cu})$, chromium $(\mathrm{Cr})$, nickel $(\mathrm{Ni})$ and lead $(\mathrm{Pb})$ [11] [12]. Some of these metals like cadmium or lead are dangerous for human health. These results show also that heavy metals are more concentrated in magnetic waste rock and less concentrated in rich phosphate rock. However, it should be noted that cadmium is concentrated in rock phosphate than in screenings and phosphate sludge. This can be explained by the fact that the concentrations of $\mathrm{Cr}, \mathrm{Cu}, \mathrm{Ni}, \mathrm{V}, \mathrm{Sr}, \mathrm{Zn}$, etc. increase with decreasing grain size while the concentration of $\mathrm{Cd}$ decreases with decreasing grain size [13].

Major element analysis results (Table 3) indicate that rock phosphate is essentially formed of calcium and phosphorus which confirms Tchangbedji and al [14] results. The screenings and the phosphate sludge mainly consist of calcium $(\mathrm{Ca})$, phosphorus $(\mathrm{P})$, silicon $(\mathrm{Si})$ and aluminum $(\mathrm{Al})$. On the other hand, magnetic waste rock is poor in silicon and aluminum but rich in iron $(\mathrm{Fe})$, calcium and phosphorus. It should also be noted that phosphate sludge has the greatest loss on ignition and the lowest rock phosphate. The chemical composition of phosphate sludge is very similar from that of screen refusals because both coming from practically the same process. But we notice that the content of the element sodium $(\mathrm{Na})$ in the phosphate sludge is almost ten times that of rock phosphate screen rejects. This increase in sodium content can be explained by seawater using for ore washing. This waste also contains traces of phosphate $20 \%$ in screen refusals, $14.2 \%$ in the phosphate slurry and $15.7 \%$ in the magnetic waste rock. 


\subsection{Thermogravimetric and Differential Thermal Analysis}

\section{1) Refusal to screens}

Figure 2 shows the Thermogravimetric (TGA) and Differential Thermal (DTA) analysis curves screen refusals. TGA curves revealed four successive mass losses in relation to four peaks of differential thermal analysis observed in the intervals of successive temperatures:

- The first interval is from room temperature to $200^{\circ} \mathrm{C}$ with a loss of mass of $3.15 \%$ of the total mass of the sample with high amplitude peak, observed on DTA curve at room temperature up to $100^{\circ} \mathrm{C}$ (top located around $70^{\circ} \mathrm{C}$ ) attributed to the departure of the water [15].

- The second mass loss of $0.91 \%$ begins around $200^{\circ} \mathrm{C}$ and extends up to $350^{\circ} \mathrm{C}$. This mass loss, the smallest, can be attributed to the desorption of water from the material structure and the decomposition of organic materials. The DTA weak amplitude peak observes between $250^{\circ} \mathrm{C}$ and $275^{\circ} \mathrm{C}$ results simultaneously from the superposition of a reaction due to the desorption of structural water and to other reactions which provide from the combustion of volatile organic materials [15].

- The third domain is between $350^{\circ} \mathrm{C}$ and $625^{\circ} \mathrm{C}$. In this interval, we detect a mass loss of $3.17 \%$ of the total sample mass. The DTA peak observed at around $480^{\circ} \mathrm{C}$ is attributed to this loss of mass due to the dehydroxylation of clay minerals such as kaolinite present in the screenings.

- The last interval between $650^{\circ} \mathrm{C}$ and $1000^{\circ} \mathrm{C}$ corresponds to a mass loss of $2.20 \%$ associated to DTA peak at around $900^{\circ} \mathrm{C}$ is due to the decomposition of carbonates with release of $\mathrm{CO}_{2}$ [16]. The overall loss at $1000^{\circ} \mathrm{C}$ is of the order of 9.43\%.

\section{2) Phosphate sludge}

The TGA and DTA curves of phosphate sludge and its derivative is reported in Figure 3. Thermogravimetric curve shows four successive mass losses in relation to four domains of temperatures which are:

- First range extends from room temperature to $200^{\circ} \mathrm{C}$. Mass loss is $3.59 \%$ of the total mass of sample. This loss corresponds to desorption of water molecules on the surface of phosphate sludge. The two peaks observed on DTA curve at low temperatures $\left(80^{\circ} \mathrm{C}\right.$ and $\left.120^{\circ} \mathrm{C}\right)$ confirm that this loss is due to the expulsion of water adsorbed on the phosphate sludge.

- Second domain is between $200^{\circ} \mathrm{C}$ and $475^{\circ} \mathrm{C}$. It corresponds to a mass loss $(1.319 \%)$ due to the departure of structural water and decomposition of organic matters [17].

- Third range is between $475^{\circ} \mathrm{C}$ and $650^{\circ} \mathrm{C}$. In this interval, we detect on TGA curve a loss of $5.21 \%$ of total mass of sample. Peak observed at around $500^{\circ} \mathrm{C}$ on DTA curve allows us to attribute this loss to the dehydroxylation of clay minerals such as kaolinite and illite present in the phosphate sludge [18] [19].

- Last loss int interval between $650^{\circ} \mathrm{C}$ and $1000^{\circ} \mathrm{C}$ on TGA curve corresponds to a mass loss of, $5.16 \%$. This loss is associated with a DTA curve peak around $840^{\circ} \mathrm{C}$. It's due to the decomposition of carbonates with the release of $\mathrm{CO}_{2}$ [8]. 


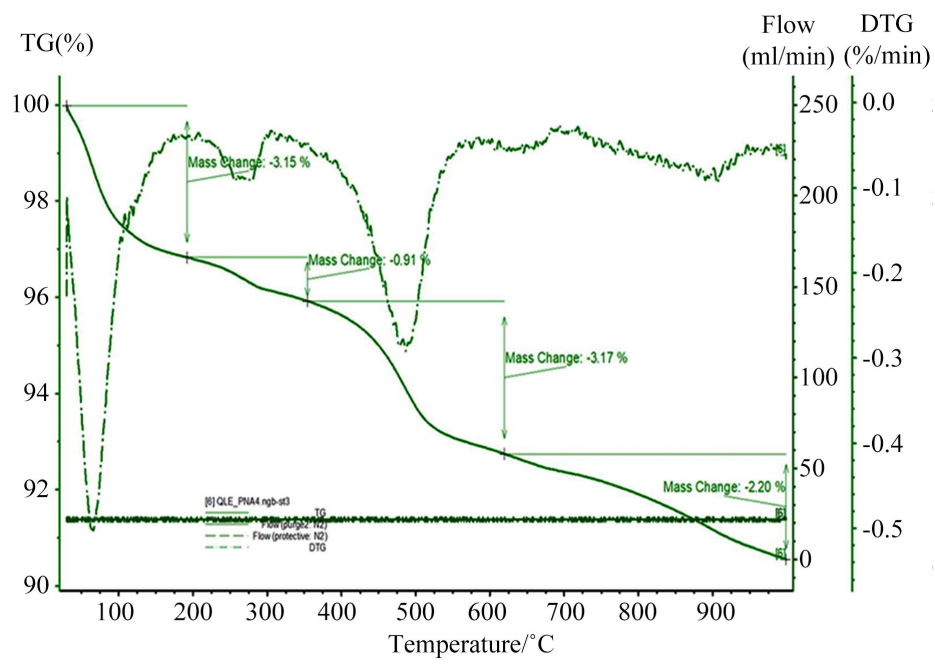

Figure 2. Thermogravimetric (TGA) and Differential Thermal (DTA) analysis curves for screen.

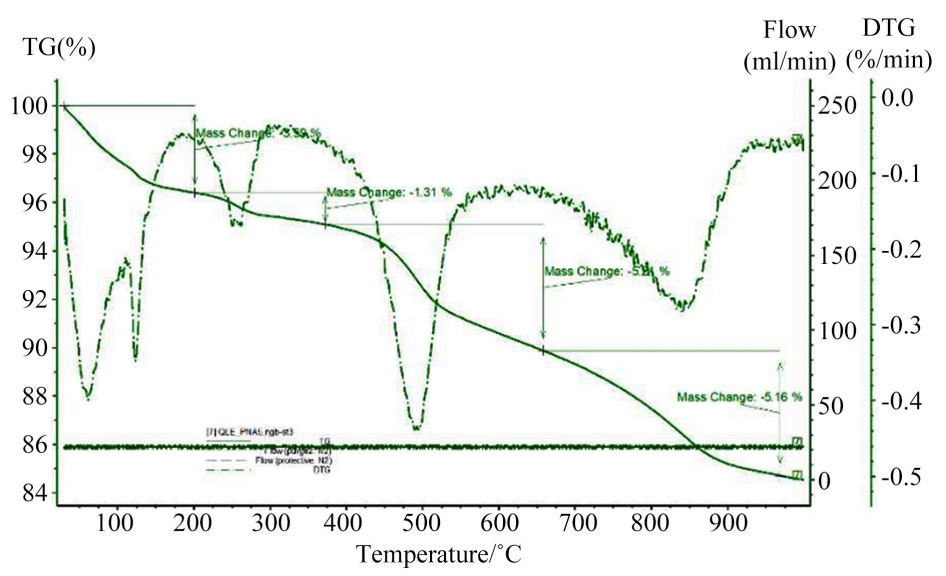

Figure 3. Thermogravimetric (TGA) and Differential Thermal (DTA) analysis curves for sludge phosphate.

Note that the overall loss at $1000^{\circ} \mathrm{C}$ is of the order of 15.27 , which is greater than in the case of screen refusals. This mass loss confirms the loss on ignition results obtained at the ICP-AES result.

\section{3) Magnetic waste}

Like the other two preceding wastes, the magnetic waste thermic analysis revealed four successive mass losses on TGA curve in relation with four temperature intervals (Figure 4).

- First interval is from room temperature to $180^{\circ} \mathrm{C}$. A loss is $1.68 \%$ of the total sample mass. This mass loss is the lowest in this area compared to the other two releases. The peak observed on differential thermal analysis curve at room temperature up to $120^{\circ} \mathrm{C}$ (peak located around $80^{\circ} \mathrm{C}$ ) is initially assigned adsorption water.

- Second loss (4.68\%) begins around $180^{\circ} \mathrm{C}$ and extends up to $400^{\circ} \mathrm{C}$. This mass loss, the greatest, can be attributed to the evaporation of constitution water of iron hydroxides. The strong amplitude peak observed on DTA curve between 
$250^{\circ} \mathrm{C}$ and $300^{\circ} \mathrm{C}$ certainly is due to the endothermic reactions due to the departure of structural water and transformation of $\alpha \mathrm{FeOOH}$ (goethite) to $\alpha \mathrm{Fe}_{2} \mathrm{O}_{3}$ (hematite) during heating.

- Third range is between $350^{\circ} \mathrm{C}$ and $625^{\circ} \mathrm{C}$. In this interval, we detect loss of $1.20 \%$ of sample mass. The observed low amplitude endothermic peak on DTA curve at around $500^{\circ} \mathrm{C}$ allows us to attribute this loss to dehydroxylation of clay minerals such as kaolinite and illite present in magnetic waste rock [20] [21].

- Last interval between $650^{\circ} \mathrm{C}$ and $1000^{\circ} \mathrm{C}$ corresponds to a mass loss of $1.32 \%$ observed on TGA curve associated to DTA curve endothermic peak around $840^{\circ}$ C. This loss is due to decomposition of carbonates with release of $\mathrm{CO}_{2}$.

We observe on TGA curve an overall mass loss of $8.88 \%$ at $1000^{\circ} \mathrm{C}$ which is lower than in the case of phosphate sludge and screen refusals.

\section{4) Dust or fine particles of phosphate}

The thermogravimetric and differential thermal curves of the fine's particles of natural phosphate of Hahotoe-Kpogame are represented in Figure 5. Analysis of these thermograms revealed four mass losses in relation to four intervals of temperature:

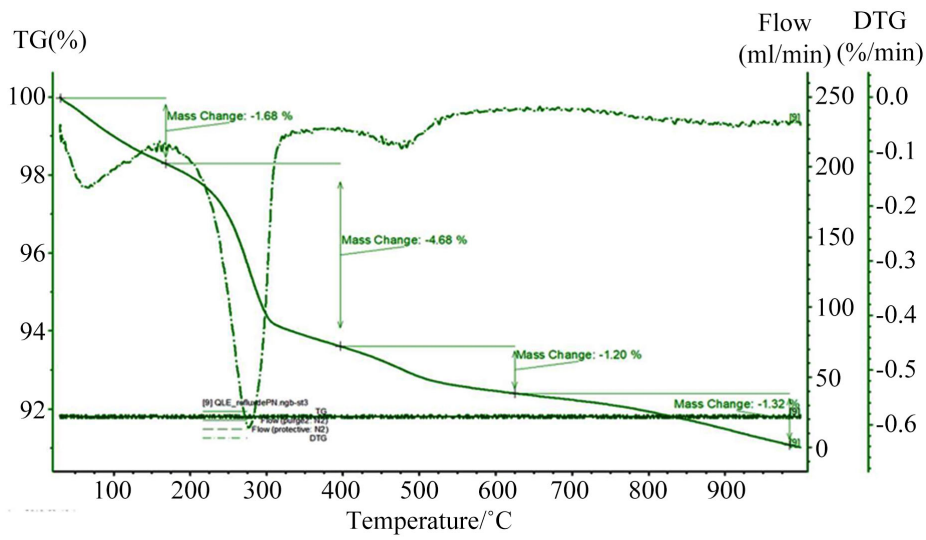

Figure 4. Thermogravimetric (TGA) and Differential Thermal (DTA) analysis curves for magnetic waste.

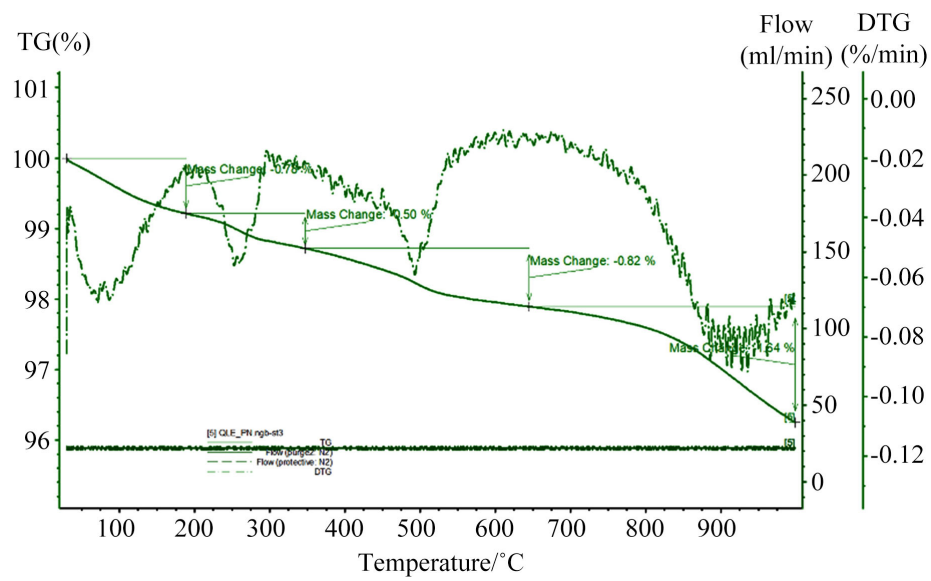

Figure 5. Thermogravimetry (TGA) and Differential Thermal (DTA) analysis curves for fine phosphate discharges. 
- First ranges from room temperature to $180^{\circ} \mathrm{C}$, loss of mass of $0.78 \%$ is detected. This loss corresponds to the desorption of water molecules adsorbed on the surface of the material [22]. It is linked to the solid by very weak cohesion forces. Most of the time, it is found on the external surfaces and in the pores of the material [22].

- Second interval is between $180^{\circ} \mathrm{C}$ and $350^{\circ} \mathrm{C}$. It corresponds to a loss of $0.50 \%$ of sample mass. This loss is attributed to the desorption of structural water and the decomposition of some organic matter little linked to phosphate material.

- Third interval is between $350^{\circ} \mathrm{C}$ and $650^{\circ} \mathrm{C}$. In this interval, we detect a loss of $0.82 \%$ total mass on TGA curve. This loss is attributed to the decomposition of part of the carbonates contained in the phosphate.

- Last interval between $650^{\circ} \mathrm{C}$ and $1000^{\circ} \mathrm{C}$ corresponds to a loss $1.64 \%$ of sample masse on TGA curve. This loss of mass can be mainly attributed to the decomposition of remaining carbonates and also the loss of water molecules during transformation structural [9].

\subsection{X-Ray Diffraction Analysis}

\section{1) Screen refusal $X$-ray diffraction analysis}

The X-ray diffraction analysis of the phosphate screens diffractogram (Figure 6) exhibits diffraction lines attributed to fluoroapatite. Indeed, this diffractogram was compared with the materials from the POW_COD file using the software "Qualx". All of the peaks of the fluoroapatite referenced to code 00-900-1390 with chemical formula $\mathrm{Ca}_{4.791} \mathrm{~F}_{0.93} \mathrm{Mn}_{0.211} \mathrm{O}_{12} \mathrm{P}_{3}$. It crystallized in the hexagonal system, belonging to the space group $\mathrm{P} 63 / \mathrm{m}$ with parameters $\mathrm{a}=\mathrm{b}=9.3596 \AA$ and $c=6.8603 \AA$, are identified in our diffractogram. Other secondary phases are also present and are attributed to quartz $\left(\mathrm{SiO}_{2}\right)$ and nacrite $\left(\mathrm{Al}_{2} \mathrm{O}_{9} \mathrm{Si}_{2}\right)$. These phases have also been identified thanks to the POW_COD file. Quartz and nacrite are referenced respectively to code 00-153-6389 and 00-154-1965.

\section{2) X-ray diffraction analysis of phosphate sludge}

$\mathrm{X}$-ray Diffractogram s of the phosphate sludge (Figure 7) shows diffraction lines attributed to fluoroapatite, referenced in the code 00-901-0504 with chemical formula $\mathrm{C}_{0.042} \mathrm{Ca}_{5} \mathrm{~F}_{0.921} \mathrm{O}_{12.321} \mathrm{P}_{2.883}$, crystallized in the hexagonal system, belonging to the space group $\mathrm{P} 63 / \mathrm{m}$ of with the parameters $\mathrm{a}=\mathrm{b}=9.3648 \AA$ and $\mathrm{c}$ $=6.8879 \AA$ A. Other secondary phases are also present and are attributed to sodium chloride $(\mathrm{NaCl})$, quartz $\left(\mathrm{SiO}_{2}\right)$ and kaolinite $\left(\mathrm{Al}_{2} \mathrm{H}_{4} \mathrm{O}_{9} \mathrm{Si}_{2}\right)$. The presence of sodium chloride is probably due to the seawater used during the washing of phosphates [23] [24].

\section{3) X-ray diffraction analysis of magnetic waste}

We are identified different mineralogical phases present in this release (Figure 8). X-ray diffractogram mainly shows lines diffraction patterns attributed to fluoroapatite referenced in the code 00-500-0041 with chemical formula $\mathrm{Ca}_{4.791}$ $\mathrm{F}_{0.93} \mathrm{Mn}_{0.211} \mathrm{O}_{12} \mathrm{P}_{3}$ crystallized in the hexagonal system, belonging to the space group P63/m with parameters $\mathrm{a}=\mathrm{b}=9.3596 \AA$ and $\mathrm{c}=6.8603 \AA$. Another secondary phase is also present and is attributed to goethite (FeOOH). This phase is 
referenced with code 00-100-8768.

\section{4) X-ray diffraction analysis of fine particles of rock phosphate}

$\mathrm{X}$-ray diffraction analysis spectrum of the rock phosphate of Hahotoe-Kpogame (Figure 9). The X-ray diffractograms of natural phosphate, presents diffraction lines attributed to the fluoroapatite phase, referenced to the code 00-100-8768 of chemical formula $\mathrm{Ca}_{4.791} \mathrm{~F}_{0.93} \mathrm{Mn}_{0.211} \mathrm{O}_{12} \mathrm{P}_{3}$, crystallized in the hexagonal system, belonging to the space group $\mathrm{P}_{3} / \mathrm{m}$ of mesh parameters $\mathrm{a}=\mathrm{b}=9.3596 \AA$ and $\mathrm{c}$ $=6.8603 \AA$.

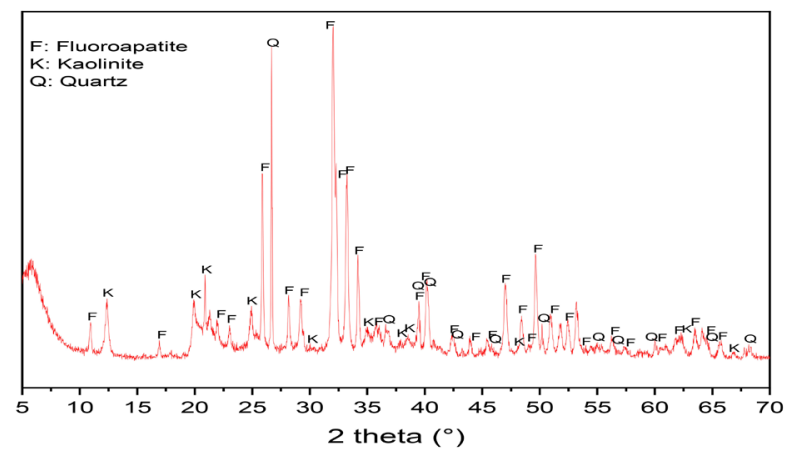

Figure 6. XRD of screen refusals.

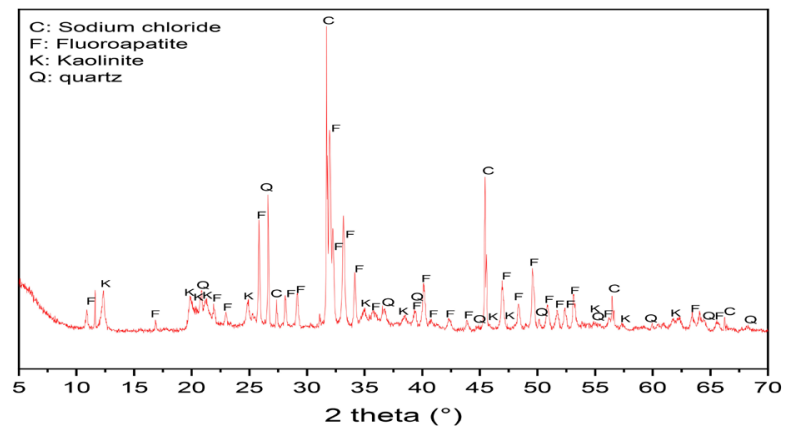

Figure 7. XRD of phosphate sludge.

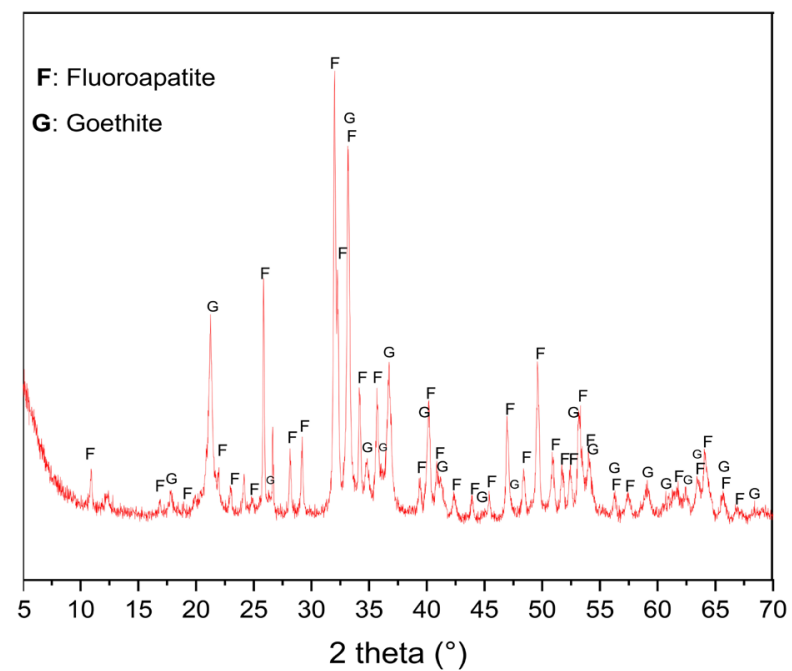

Figure 8. XRD of magnetic waste. 


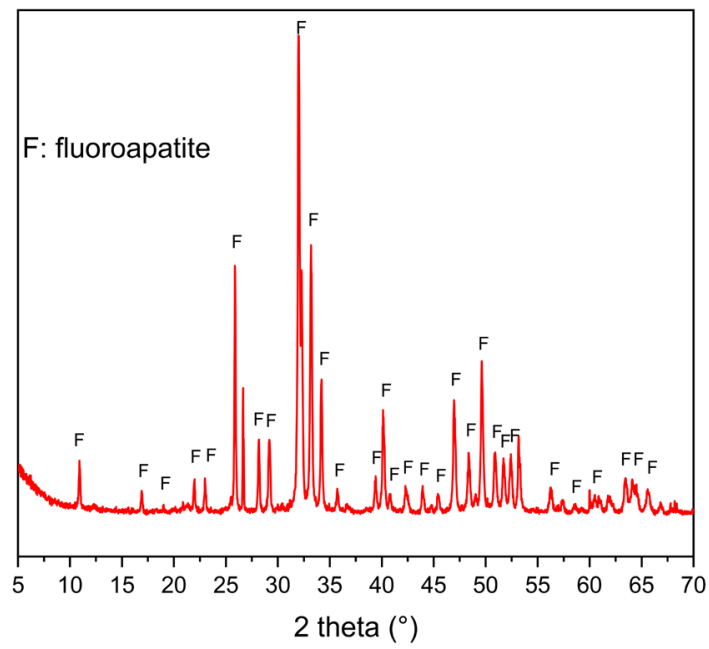

Figure 9. XRD of fine phosphate particles.

\section{Fourier Transform Infrared Spectroscopy Analysis}

\section{1) Fourier transform infrared spectroscopy analysis of screen refusals}

The infrared spectrum of screen refusals (Figure 10) shows a wide band in the hydroxyl elongation zone. These peaks are located at $3695 \mathrm{~cm}^{-1}$ and $3620 \mathrm{~cm}^{-1}$. The small band located at $1600 \mathrm{~cm}^{-1}$ and $1650 \mathrm{~cm}^{-1}$ correspond to the angular deformations of the connections $\mathrm{O}-\mathrm{H}$ water molecules [25]. The spectrum also presents bands at $1450 \mathrm{~cm}^{-1}, 1430 \mathrm{~cm}^{-1}$ and $870 \mathrm{~cm}^{-1}$ characteristics of carbonates [22]. The remaining bands are common to two different phases. We attribute the band located at $1040 \mathrm{~cm}^{-1}$ to elongations either of $\mathrm{Si}-\mathrm{O}$ or to phosphate groups $\left(\mathrm{PO}_{4}^{3-}\right.$ ) [26] [27]. The band located around $500 \mathrm{~cm}^{-1}$ is attributed to deformation either of Si-O-Si or phosphate groups $\left(\mathrm{PO}_{4}^{3-}\right)$. The bands detected at $1096 \mathrm{~cm}^{-1}$, $602 \mathrm{~cm}^{-1}$ and $570 \mathrm{~cm}^{-1}$ may correspond with phosphate ions $\left(\mathrm{PO}_{4}^{3-}\right)$ [26].

2) Fourier transform infrared spectroscopy analysis of sludge from phosphates

The infrared spectrum of phosphate sludge (Figure 11) is almost identical to that of screen refusal. The same bands are observed in the sludge of phosphate. The spectrum shows a band in the zone of the elongations of the hydroxyls located at $3695 \mathrm{~cm}^{-1}$ and $3620 \mathrm{~cm}^{-1}$. The small band located $1600 \mathrm{~cm}^{-1}$ and 1650 $\mathrm{cm}^{-1}$ correspond to the angular deformations of the $\mathrm{O}-\mathrm{H}$ bonds of water molecules [25]. Spectrum also shows the bands at $1450 \mathrm{~cm}^{-1}, 1430 \mathrm{~cm}^{-1}$ and $870 \mathrm{~cm}^{-1}$ characteristics of carbonates [22]. The remaining bands are common to two different phases. We assign the band located at $1040 \mathrm{~cm}^{-1}$ to elongations either of Si-O or of phosphate groups $\left(\mathrm{PO}_{4}^{3-}\right)$ [26] [27]. The band located around 500 $\mathrm{cm}^{-1}$ is attributed to the deformations either of $\mathrm{Si}-\mathrm{O}-\mathrm{Si}$ or to groups phosphates $\left(\mathrm{PO}_{4}^{3-}\right.$ ). The bands detected at $1096 \mathrm{~cm}^{-1}, 602 \mathrm{~cm}^{-1}$ and $570 \mathrm{~cm}^{-1}$ may correspond with phosphate ions $\left(\mathrm{PO}_{4}^{3-}\right)$ [16].

3) Analysis by infrared spectroscopy to Fourier transform of waste rock magnetic waste

The infrared spectrum of the magnetic waste (Figure 12) shows a large band of hydroxyl elongations located at $3695 \mathrm{~cm}^{-1}$ and $3620 \mathrm{~cm}^{-1}$ are detected. The 
small band located at $1600 \mathrm{~cm}^{-1}$ and $1650 \mathrm{~cm}^{-1}$ correspond to the angular deformations of the $\mathrm{O}-\mathrm{H}$ bonds of water molecules [28]. We detect also on spectrum bands at $581 \mathrm{~cm}^{-1}$ and at $576 \mathrm{~cm}^{-1}$ corresponding to groupings of $\mathrm{Fe}_{3} \mathrm{O}_{4}$.

4) Fourier-transmitted infrared spectroscopy of fine particles of Hahotoe-Kpogame phosphate

Infrared spectrum of fine particles of rock phosphate (Figure 13) has a lot of similarity with the previous spectra. This spectrum presents as spectrum of the phosphate sludge and the rejects, bands at $1450 \mathrm{~cm}^{-1}, 1430 \mathrm{~cm}^{-1}$ and $870 \mathrm{~cm}^{-1}$, characteristic of carbonates [29], band located at $1040 \mathrm{~cm}^{-1}$ attributed to elongations either of Si-O or to groups phosphates $\left(\mathrm{PO}_{4}^{3-}\right)$, band around $570 \mathrm{~cm}^{-1}$ affected by deformations of either $\mathrm{Si}-\mathrm{O}-\mathrm{Si}$ or either has phosphate groups $\left(\mathrm{PO}_{4}^{3-}\right)$ and finally bands detected at $1096 \mathrm{~cm}^{-1}, 602 \mathrm{~cm}^{-1}$ and $570 \mathrm{~cm}^{-1}$ can corresponding to phosphate ions $\left(\mathrm{PO}_{4}^{3-}\right)[30]$.

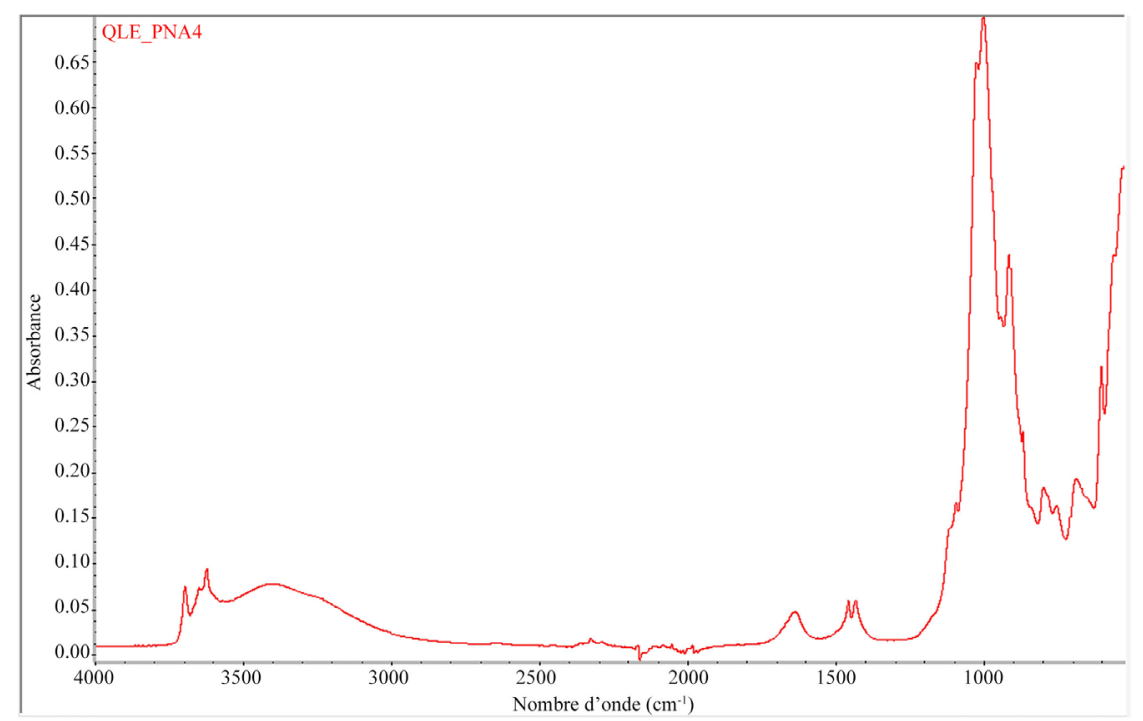

Figure 10. Infra-Red spectrum of screen refusals.

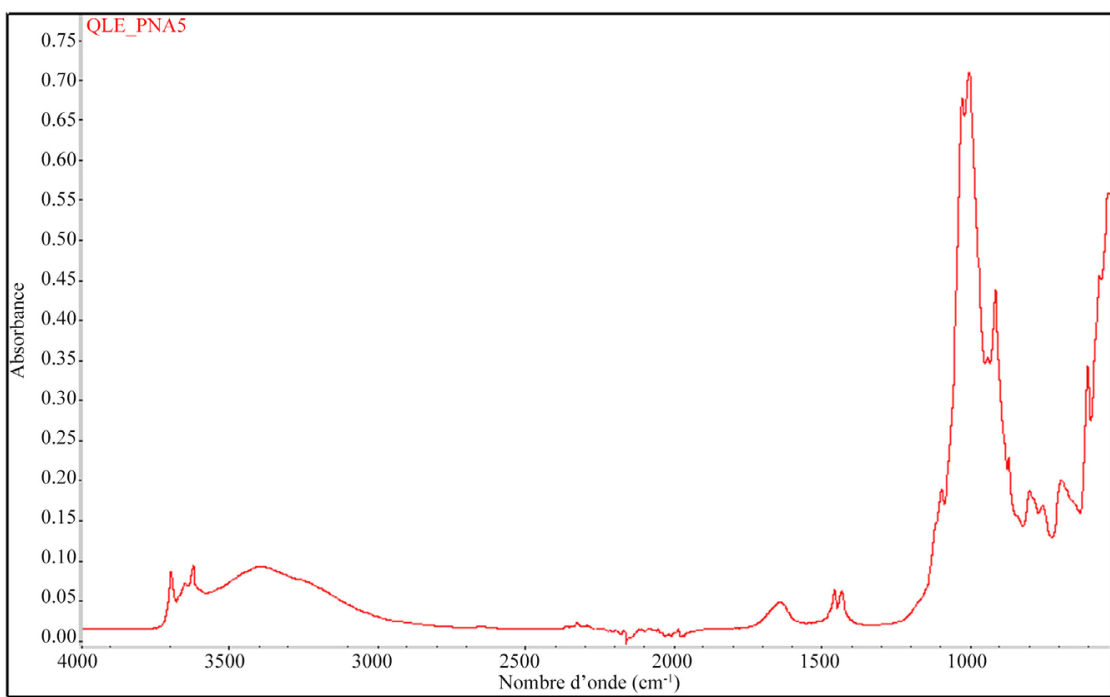

Figure 11. Infra-Red spectrum of phosphate sludge. 


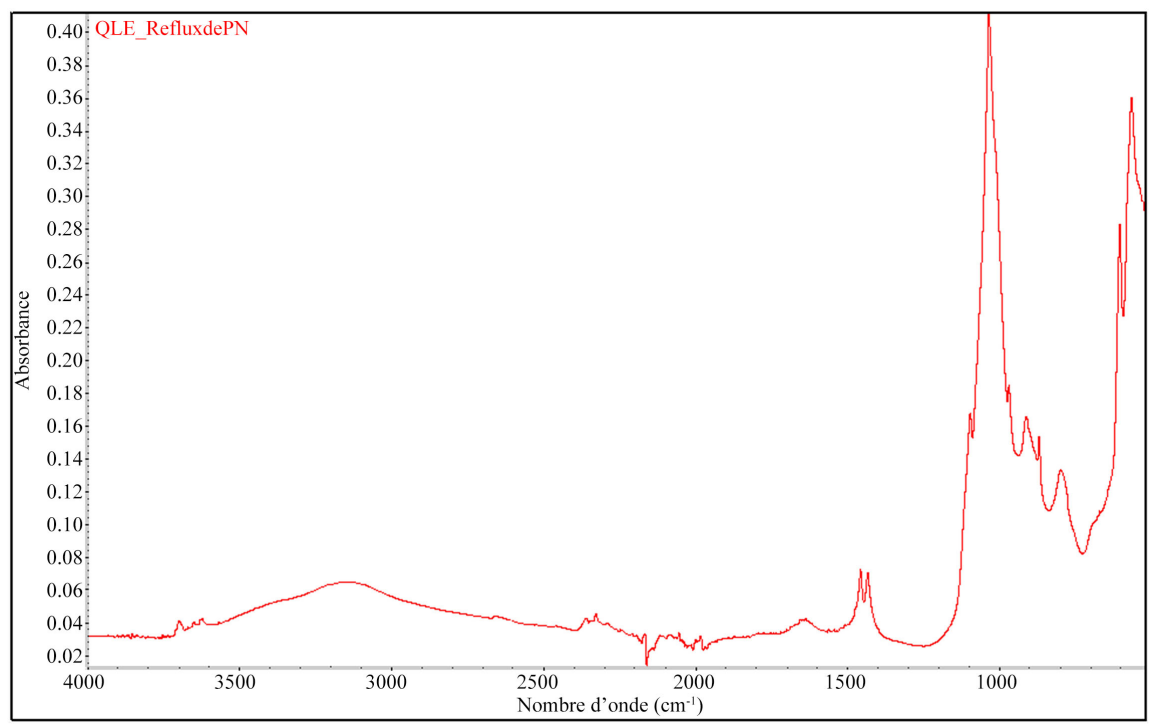

Figure 12. Infra-Red spectrum of magnetic waste.

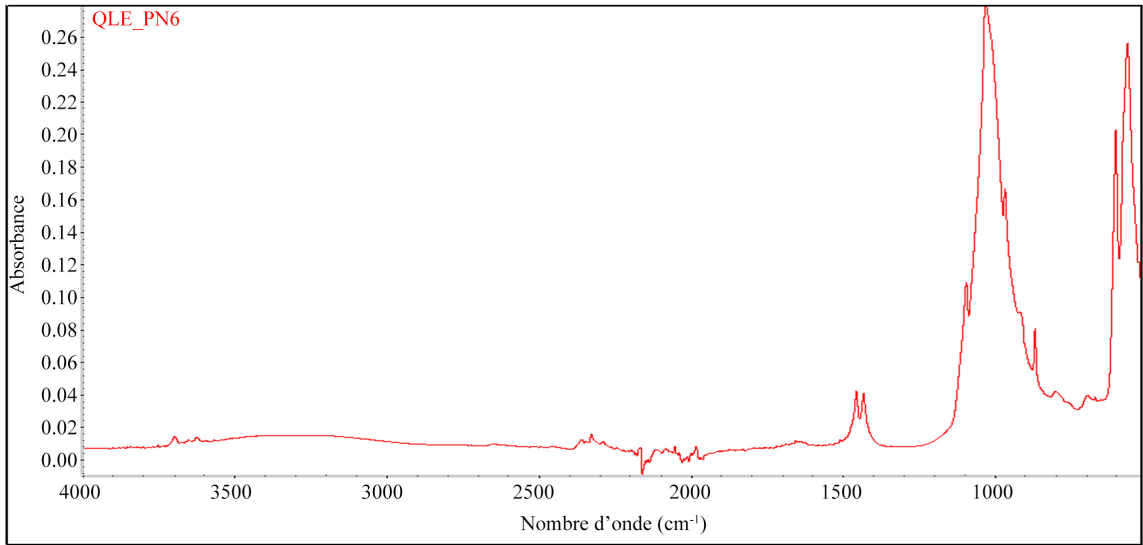

Figure 13. Infra-Red spectrum of fine particles of phosphate.

\section{Conclusions}

Physicochemical analyses of different types of wastes of natural phosphate ore from Hahotoe-Kpogame (Togo) treatments have been performed. The results that we have obtained show that sludge is essentially clay (Kaolinite), goethite, glauconite, apatite (phosphate) and silica. They are mainly composed of clays but there is also phosphate material. The results have also revealed the presence of elements belonging to phosphate material or clays such as phosphorus $(\mathrm{P})$, iron $(\mathrm{Fe})$, Aluminum $(\mathrm{Al})$ and carried out that screen refusals are mainly composed of calcium, phosphorus, silicon and aluminum, magnetic waste rock is poor in silicon and aluminum but rich in iron (Fe), phosphorus and heavy metals but mainly formed of goethite.

These results open up interesting perspectives of the valorization of different discharges. The phosphate sludge and the refusal to screen could be used in conventional ceramics or in functional ceramics: light aggregates in hydroponics, aggregates for thermal and acoustic insulation, bricks, mortars, concretes, 
filtering membranes for water decontamination and effluent treatment, geopolymers, etc. This recovery process is original and considered as an alternative solution since it is a large consumer of raw materials. One can also imagine applications in technical ceramics which cover the fields of health and optics, aeronautics and aerospace, transport and energy, and electronics. Magnetic waste rock rich in iron $(\mathrm{Fe})$ can be used in heterogeneous photocatalysis based on iron ore for the treatment of residual liquid waste. Phosphate dust or fine particle of phosphates can be used instead of natural phosphate rock.

\section{Acknowledgements}

Authors would like to thank all the technical staff of different Laboratories in French (LAGEPP) and Canada (INRS) for their help for his acceptance to perform physicochemical characterization of our materials. This work was financially supported by the International Development Research Centre (IDRC) of Canada through the project FGéPro (Training in Industrial Process Engineering for Treatment and Valorization of Agricultural/Agro-industrial Waste in High Added Value Products).

\section{Conflicts of Interest}

The authors declare no conflicts of interest regarding the publication of this paper.

\section{References}

[1] Lechner, M. and Freiberger, E. (2011) Société Nouvelle des Phosphates du Togo, Etude de faisabilité sur l'utilisation de la boue de station de traitement des eaux usées proposée pour la Société Nouvelle des Phosphates du Togo. UNIDO Final Report.

[2] Agbossoumonde, D.Y. (2011) Les problèmes liés à l'extraction des ressources naturelles au Togo: Le cas des phosphates de hahotoé-kpogamé et des calcaires de Tabligbo au Sud Togo, 10.

[3] Gnandi, K. and Tobschall, H.J. (1999) Heavy Metal Release from Phosphorite tailings into Seawater: A Simulated Laboratory Study. Science of the Total Environment, 236, 181-190. https://doi.org/10.1016/S0048-9697(99)00279-X

[4] Aduayi-Akue, A.A., Gnandi, K., Tete-Benissan, A., Degbe, M., Tanouayi, G. and Gbeassor, M. (2015) Evaluation des teneurs des métaux lourds dans le sang des sujets de la zone de traitement des phosphates au Sud du Togo. International Journal of Biological and Chemical Sciences, 9, 1972-1982. https://doi.org/10.4314/ijbcs.v9i4.22

[5] Gnandi, K., Tchangbedji, G., Killi, K., Baba, G. and Abbe, K. (2006) The Impact of Phosphate Mine Tailings on the Bioaccumulation of Heavy Metals in Marine Fish and Crustaceans from the Coastal Zone of Togo. Mine Water and the Environment, 25, 56-62. https://doi.org/10.1007/s10230-006-0108-4

[6] Gnandi, K. and Tobschall, H.J. (1999) The Pollution of Marine Sediments by Trace Elements in the Coastal Region of Togo Caused by Dumping of Cadmium-Rich Phosphorite Tailing into the Sea. Environmental Geology, 38, 13-24. https://doi.org/10.1007/s002540050396 
[7] Anh Tuan, B.L., Tesfamariam, M.G., Chen, Y.-Y., Hwang, C.-L., Lin, K.-L. and Young, M.-P. (2014) Production of Lightweight Aggregate from Sewage Sludge and Reservoir Sediment for High-Flowing Concrete. Journal of Construction Engineering and Management, 140, 401-405. https://doi.org/10.1061/(ASCE)CO.1943-7862.0000835

[8] Boudaghpour, S. and Hashemi, S. (2008) A Study on Light Expended Clay Aggregate (LECA) in a Geotechnical View and Its Application on Greenhouse and Greenroof Cultivation. International Journal of Geology, 2, 59-63.

[9] Chang, F.-C., Lo, S.-L., Lee, M.-Y., Ko, C.-H., Lin, J.-D., Huang, S.-C. and Wang, C.-F. (2007) Leachability of Metals from Sludge-Based Artificial Lightweight Aggregate. Journal of Hazardous Materials, 146, 98-105. https://doi.org/10.1016/j.jhazmat.2006.11.069

[10] Liu, D., Løkke, M.M., Leegaard Riis, A., Mortensen, K. and Feilberg, A. (2014) Evaluation of Clay Aggregate Biotrickling Filters for Treatment of Gaseous Emissions from Intensive Pig Production. Journal of Environmental Management, 136, 1-8. https://doi.org/10.1016/j.jenvman.2014.01.023

[11] González-Corrochano, B., Alonso-Azcárate, J. and Rodas, M. (2009) Characterization of Lightweight Aggregates Manufactured from Washing Aggregate Sludge and Fly Ash. Resources, Conservation and Recycling, 53, 571-581.

https://doi.org/10.1016/j.resconrec.2009.04.008

[12] Olesik, J.W. (1991) Elemental Analysis Using ICP-OES and ICP/MS. Analytical Chemistry, 63, 12A-21A. https://doi.org/10.1021/ac00001a711

[13] Ramsey, M.H., Potts, P.J., Webb, P.C., Watkins, P., Watson, J.S. and Coles, B.J. (1995) An Objective Assessment of Analytical Method Precision: Comparison of ICP-AES and XRF for the Analysis of Silicate Rocks. Chemical Geology, 124, 1-19. https://doi.org/10.1016/0009-2541(95)00020-M

[14] Tchangbedji, G., Djetelim G., Kilim A,K., Savariaul, M.J. and Lacout, J.L. (2003) Chemical and Structural Characterization of Natural Phosphate of Hahotoé (TOGO). Bulletin of the Chemical Society of Ethiopia, 17, 1-8. https://doi.org/10.4314/bcse.v17i2.61659

[15] Ropp, R.C. and Aia, M.A. (1962) Thermal Analysis of Phosphor Raw Materials. Analytical Chemistry, 34, 1288-1291. https://doi.org/10.1021/ac60190a026

[16] Koenig, J.L. (1975) Application of Fourier Transform Infrared Spectroscopy to Chemical Systems. Applied Spectroscopy, 29, 293-308. https://doi.org/10.1366/000370275774455888

[17] Kong, J. and Yu, S. (2007) Fourier Transform Infrared Spectroscopic Analysis of Protein Secondary Structures. Acta Biochimica et Biophysica Sinica, 39, 549-559. https://doi.org/10.1111/j.1745-7270.2007.00320.x

[18] Gnandi, K., Rezaie Boroon, M.H. and Edorh, P. (2009) The Geochemical Characterization of Mine Effluents from the Phosphorite Processing Plant of Kpémé (Southern Togo). Mine Water and the Environment, 28, 65-73. https://doi.org/10.1007/s10230-008-0058-0

[19] Mangialardi, T. (2001) Sintering of MSW Fly Ash for Reuse as a Concrete Aggregate. Journal of Hazardous Materials, 87, 225-239. https://doi.org/10.1016/S0304-3894(01)00286-2

[20] Merino, I., Arévalo, L.F. and Romero F. (2005) Characterization and Possible Uses of Ashes from Wastewater Treatment Plants. Waste Management, 25, 1046-1054. https://doi.org/10.1016/j.wasman.2004.12.023

[21] Loutou, M., Hajjaji, M., Mansori, M., Favotto, C. and Hakkou, R. (2013) Phosphate 
Sludge: Thermal Transformation and Use as Lightweight Aggregate Material. Journal of Environmental Management, 130, 354-360. https://doi.org/10.1016/j.jenvman.2013.09.004

[22] Walter, D., Buxbaum, G. and Laqua, W. (2001) The Mechanism of the Thermal Transformation from Goethite to Hematite. Journal of Thermal Analysis and Calorimetry, 63, 733-748. https://doi.org/10.1023/A:1010187921227

[23] Lee, V.-G. and Yeh, T.-H. (2008) Sintering Effects on the Development of Mechanical Properties of Fired Clay Ceramics. Materials Science and Engineering. A, 485, 5-13. https://doi.org/10.1016/j.msea.2007.07.068

[24] Liu, M., Wang, C., Bai, Y. and Xu, G. (2018) Effects of Sintering Temperature on the Characteristics of Lightweight Aggregate Made from Sewage Sludge and River Sediment. Journal of Alloys and Compounds, 748, 522-527. https://doi.org/10.1016/j.jallcom.2018.03.216

[25] Lee, J., Isobe, T. and Senna, M. (1996) Preparation of Ultrafine $\mathrm{Fe}_{3} \mathrm{O}_{4}$ Particles by Precipitation in the Presence of PVA at High pH. Journal of Colloid and Interface Science, 177, 490-494. https://doi.org/10.1006/jcis.1996.0062

[26] González-García, F., Romero-Acosta, V., García-Ramos, G. and González-Rodríguez, M. (1990) Firing Transformations of Mixtures of Clays Containing Illite, Kaolinite and Calcium Carbonate Used by Ornamental Tile Industries. Applied Clay Science, 5, 361-375. https://doi.org/10.1016/0169-1317(90)90031-J

[27] Jordán, M.M., Martín-Martín, J.D., Sanfeliu, T., Gómez-Gras, D. and de la Fuente, C. (2009) Mineralogy and Firing Transformations of Permo-Triassic Clays Used in the Manufacturing of Ceramic Tile Bodies. Applied Clay Science, 44, 173-177. https://doi.org/10.1016/j.clay.2009.01.018

[28] Srasra, E. (1994) Infrared Spectroscopy Study of Tetrahedral and Octahedral Substitutions in an Interstratified Illite-Smectite Clay. Clays and Clay Minerals, 42, 237-241. https://doi.org/10.1346/CCMN.1994.0420301

[29] Hajjaji, M., Kacim, S., Alami, A., El Bouadili, A. and El Mountassir, M. (2001) Chemical and Mineralogical Characterization of a Clay Taken from the Moroccan Meseta and a Study of the Interaction between Its Fine Fraction and Methylene Blue. Applied Clay Science, 20, 1-12. https://doi.org/10.1016/S0169-1317(00)00041-7

[30] Almeida, R.M. and Pantano, C.G. (1990) Structural Investigation of Silica Gel Films by Infrared Spectroscopy. Journal of Applied Physics, 68, 4225-4232. https://doi.org/10.1063/1.346213 